\title{
Male Choice and Desire: Material Offerings in Seventeenth-Century
}

\section{England}

In 1596, Thomas Lyte, of Lytes Cary Manor in Somerset, commissioned a ring for his soon-to-be wife, Frances Worth. Inside the ring, Thomas crafted a carefully composed inscription. This read, 'Lytes Love is little worth. ${ }^{1}$ The inscription was a wordplay. It made light of early modern criticisms on love being second string to economics and status in marriage, while Joan Evans, the jewellery collector and early material culturist, noted that Frances Worth was said to be of small stature. ${ }^{2}$ Thomas Lyte was evidently a man who delighted in words and witty prose. A decade or so after Thomas gave this gift, William Camden described Thomas as a man 'studious of all good knowledge' in his great account of England, Scotland and Ireland. ${ }^{3}$ For Thomas, his tailored, humorous and individual inscription reflected his mastery of words, as well as creating a personalised and sentimental gift for his wife, Frances. Thomas was typical of a new group of men and women, who found themselves with a greater disposable income than generations before, and with more ways to spend that income on individualised and sentimental objects.

${ }^{1}$ Cited in: Joan Evans, English Posies and Posy Rings (Oxford University Press, 1931), xxi.

${ }^{2}$ Evans, English Posies, xxi.

${ }^{3}$ William Camden, Britain: Or, A Chorographicall Description of the Most Flourishing Kingdomes, England, Scotland, and Ireland, and the Ilands Adioyning Out of the Depth of Antiquitie: Beautified with Mappes (London: Eliot's Court Press, 1610), 224. A later reference: Anthony à Wood, Athena Oxonienses, an Exact History of All the Writers and Bishops who Have Had Their Education in the Most Ancient and Famous University of Oxford, Volume One (1691), 533. 
At the beginning of the early modern period, England's craftsmen, shop-keepers, and peddlers were awash with new goods. Some of these were exotic, including tortoiseshell combs and snuffboxes, encapsulating the exotic aura of the New World, while some came from the East, including spices and woven fabrics. Some of the new types of goods reflected the ever-growing body of skilled artisans on the continent and in England, from delicate glass engraving in Venice through to the Lyte's posy ring. These changes and advancements transformed the marketplace of goods. ${ }^{4}$ Goods were not just more diverse but also produced in much greater number, which in turn enabled a richer scale of commodity. By 'scale' of commodity, I refer to the quality of materials and production. This scale, in which the expense of a ring could vary from the absolute minimum (if it was hand-made from animal bone, for example) through to hundreds of pounds, meant more people were able to buy or to make objects. This in turn created a great variety from object to object. And importantly for this article, this commercial revolution enabled people to more richly personalise their objects, which was an essential tool in assigning sentimentality to their objects.

This article examines the processes of amorous gift exchange available to men, predominantly from a middling to wealthy background, in the seventeenth century. Research into how objects connect to and inform us about emotions is a burgeoning area of study. As the field of material culture and the history of emotions have become

${ }^{4}$ Giorgio Riello, 'Global Things: Europe's early modern material transformation' in Catherine Richardson, Tara Hamling and David Gaimster, eds, The Routledge Handbook of Material Culture in Early Modern Europe (Abingdon: Routledge, 2017), 29-45. Alexandra Walsham, 'Domesticating the Reformation: Material Culture, Memory, and Confessional Identity in Early Modern England' in Renaissance Quarterly, 69:2, (Summer, 2016), 566-616. 
established and increasingly influential, scholars are looking toward understanding the connection between the two. ${ }^{5}$ As Sarah Randles put it, 'Further consideration needs to be given to the specifics of materiality and emotion in early modern Europe, in order to relate the emotional responses of early modern humans to the contemporary objects which they encountered, and to understand how those relationships might change over time and as the result of changes to the social, political or religious environment. ${ }^{6}$ In this article, I use objects to uncover some of the key designs and motifs of amorous materiality, and their associated symbolisms and metaphors. These highlight specific distinctions in how men expressed amorous feeling. Finally, I reflect upon the anxieties caused when using objects to represent revered feelings. Therefore this article will examine and interrogate channels of amorous expression to provide an understanding of the complexities and power of material culture in love.

Objects reveal a new layer to early modern life, where they were used to communicate, foster and celebrate all types of emotions. This article aims to explore precisely this by using objects, alongside others sources, as a means to understand amorous rituals of material expression among men. The sources in this article form part of an extensive body of over 1000 objects and 500 paper documents, including letters, broadsides, pamphlets, letters and diaries, assimilated as part of my doctoral thesis. The objects were gathered from an in-depth search in a variety of settings including museums, entrusted and private collections, and objects on sale. All objects within the

\footnotetext{
${ }^{5}$ Stephanie Downes, Sally Holloway and Sarah Randles, eds, Feeling Things: Objects and Emotions through History (Oxford: Oxford University Press, 2018).

${ }^{6}$ Sarah Randles, 'Materiality' in Susan Broomhall, ed., Early Modern Emotions: An Introduction (Abingdon: Routledge, 2017), 19.
} 
doctoral corpus date to the early modern period with a strong English provenance; for the purposes of this much smaller article, the chronological period has been limited to the seventeenth century. The parameters of their connection to love were defined by four determinants: material, design, function and provenance. ${ }^{7}$

The presence of surviving love objects and their corroborating sources demonstrate the desires and motivations of the object creators and practitioners. In light of the evolution of approaches to the history of material culture, wherein we consider whether history comes 'from' or 'through' objects, whether we should consider material culture 'and' its histories, or more simply 'write material culture history,' this article is a contribution to recovering history under the steering or guidance of objects. ${ }^{8}$ As the objects under discussion enabled emotional expressions and rituals, here material culture is a driver of history, although the intentions, aims and desires of those who used the objects are nevertheless of importance. The objects communicate their feelings through two key means. The first are objects that were used by lovers to communicate feeling: these were objects given and received, commissioned and made by hand to be given to a lover. The second are objects whose being (in some way) communicates

${ }^{7}$ For a detailed description of how the source body was gathered and refined see, Sarah Ann Robin, 'Pictures Posies and Promises: Love and the Object in the Seventeenth Century' (Unpublished doctoral thesis, Lancaster University, 2016), chapter one.

${ }^{8}$ Steven D. Lubar and William David Kingery, History from Things: Essays on Material Culture (Smithsonian Press, 1993). Leonie Hannan and Sarah Longair, History through Material Culture (Manchester University Press, 2017). Paula Findlen, Early Modern Things: Objects and their Histories, 1500-1800 (Abingdon: Routledge, 2012). Anne Gerritsen and Giorgio Riello, eds, Writing Material Culture History (New York: Bloomsbury, 2015). 
understandings of how male lovers expressed amorous feeling. This latter group may not have been used by the lover directly, but form part of the highly expressive and valuable community of surviving early modern objects connected to love rituals.

The decision to focus upon men and the channels of emotional expression available to them was driven by a continued gender imbalance within early modern studies. The majority of studies which have focused on relationships, marriage and family are written about women. ${ }^{9}$ In the last decade, a small but important number of historians have attempted to redress that imbalance, with notable examples including works by Alexandra Sheppard and Mark Breitenberg. ${ }^{10}$ These studies have painted a sensitive and nuanced picture of manhood and ideologies of men. More work is needed however to better understand how men viewed, experienced and felt about marriage. This article continues to redress the imbalance in the gendered history of marriage. It should be noted that in revealing the rituals and expressions used by men, this inevitably sheds light upon and is connected to the history of women too.

\footnotetext{
${ }^{9}$ For example: Antonia Fraser, The Weaker Vessel: Woman's Lot in Seventeenth-Century England (London: Phoenix Press, 1999). Sara Mendleson and Patricia Crawford, Women in Early Modern England 1550 - 1720 (London: Oxford University Press, 2000).

${ }^{10}$ Alexandra Sheppard, Meanings of Manhood in Early Modern England (Oxford: Oxford University Press, 2006). Mark Breitenberg, Anxious Masculinity in Early Modern England (Cambridge: Cambridge University Press, 2010). Raffaella Sarti, 'Men at Home: Domesticities, Authority, Emotions and Work, Thirteenth-Twentieth Centuries' in Gender \& History, 27:3 (November, 2015), 521-558.
} 
I focus upon heterosexual relationships and understandings of love. This is because much of what material culture reveals about love is connected to wider communal, social and religious understandings of love. These, unfortunately, do not include or acknowledge homosexual love as a viable or recognised form of love. By this, I do not believe that many of the findings of my research could not be transferrable to homosexual relationships. Furthermore, I hope that in the future a large enough body of material culture may come to light which allows in-depth analysis of homosexual love in the early modern period. However, clarity on homosexual relationships requires an approach different to the analysis on heterosexual relationships I reflect upon here.

The focus is upon the seventeenth century, largely due to the aforementioned commercial revolution, which began in the sixteenth century, and gained great momentum in the century following. ${ }^{11}$ This paved the way for larger scale production in the eighteenth century, notably in the manufacture of ceramics, textiles and foods. The majority of articles in this special issue situate their emotional histories of objects against the eighteenth century and modern period of production. My research is situated at a point where the number of domestic objects was increasing dramatically, but the majority were still created by individuals. If there was a line of production, it was likely to be in the tens, rather than the hundreds or thousands. Many of the objects were produced by lone craftsmen, cobbling and crafting the materials available to them into objects of feeling - either for themselves or customers and patrons. One such example is Robert Mindum, who between 1593 and 1612, produced and engraved objects made from animal horn and bone. He then gave these to his friends, and also to his wife, Jane

\footnotetext{
${ }^{11}$ Paul Slack, 'Material Progress and the Challenge of Affluence in Seventeenth-Century England' in The Economic History Review, 62:3 (Aug., 2009), 576-603.
} 
Mindum. ${ }^{12}$ The precise motivations of this man are not clear but his role in the creation of these objects was of central importance, as many of the surviving horns are carved with an inscription explaining how these were 'made by the hands of Robert Mindum'. ${ }^{13}$

Robert Mindum is a useful example precisely because he chose to inscribe his objects, thus allowing the historian to group together his surviving objects by creator. However, many of the creators, craftspeople and artists of seventeenth-century domestic objects are now anonymous to us. They might include an adolescent girl learning the virtues of embroidery by creating small but precious and symbolically rich objects that she may have given as a gift, or kept for herself; a lover who decided to weave her or his hair into a bracelet or piece of fabric; a roof-worker who used his remaining portion of lead to cast a heart-shaped weight, with crudely moulded initials of him and his beloved. While these creators may be nameless, the fruits of their labour survive in their thousands, and reveal a landscape of emotional material exchange and associated rituals.

Designs of Love

${ }^{12}$ Joan Evans, 'Shoe-horns and a Powder Flask' in The Burlington Magazine for Connoisseurs, 85:500 (Nov., 1944): 282-4. Alternative spelling Robart Mindvm. Examples of his work include: Shoe Horn (1593). Salisbury and South Wiltshire Museum: SWMSH1. Shoe Horn (1613). Agecroft Hall, Virginia: 1985.0007

${ }^{13}$ Evans, 'Shoe-horns and a Powder Flask' in The Burlington Magazine for Connoisseurs, 2824. Further reading: Sue Brandon, Buttonhooks and Shoehorns (Oxford: Shire Publications, 1984) 
Amorous design that represented heterosexual romantic relations was an evolving language in the early modern period and amorous representations achieved central importance within households. Figures of men and women in close proximity are captured on all kinds of domestic objects, from utensils to portraits, and embroidery to print culture. ${ }^{14}$ The most commonly found representation of an amorous union are initials. Sometimes this involved the two sets of initials side by side, or in the initial triad, with first name initials and groom's surname initial, displayed in a triangle. These initials are found on everything from house datestones to pewter skillets, and oak settles to jewellery. ${ }^{15}$ A representation of two genders coming together was a useful and often essential tool for lovers who wanted to either celebrate or communicate their desire for union. In the early modern world, male and female figures, usually of similar and equal

${ }^{14}$ Examples of print: Anon., Amintor's Answer to Parthenia's Complaint (London: P. Brooksby, 1672-1696); Anon., Halfe a Dozen of Good Wives (London, 1630-1649); Anon., A New Ballad, Intituled, The Stout Cripple of Cornwall (London: William Thackery, 16891692). Portraiture: Paul Holme, Portrait of The Holme Family (1628); The V\&A: W.5-1951. Dimensions: 11.5 x 190.5 cm (open). Utensils: Marriage Bowl (1608). Snowshill Manor (NT). Diameter: $42.5 \mathrm{~cm}$; Thomas Toft, Commemorative Wedding Dish of James II and Anne Hyde (c.1670). The Ashmolean: AN1949.343. Diameter: 32 cm; Embroidered Box (c.1660). East Riddlesden Hall (NT): 147156. Dimensions: approx. 10 x 15 cm.

${ }^{15}$ Examples include: Bed (1590). V\&A: W.101949. Dimensions: 45.7 x $175.3 \mathrm{~cm}$ (length 238.8 cm). Motif: 'TB MB'; Refectory Table (1613). Owned by Burnley Government, located at Townley Hall: BGfuan001. Dimensions: 3m (1). Inscription: 'WB + SB 1613'; Skillet (1670). The Museum of London: 80.271/10. Height: $17.8 \mathrm{~cm}$; Wine Bottle (1641). The British Museum: 1887,0307,E.18. Dimensions: 149 cm. Motif: R/E below S, 1641, renish wine; Tankard (16901710). The Museum of London: A16808. Dimensions: $12.4 \mathrm{~cm}$ high. 
size, and depicted in close proximity, were widely understood as representing husband and wife, or a courting or betrothed couple.

If we begin with this as our central amorous design, we can determine that lovers adopted this formula and personalised it in a myriad of ways, whether those were by using the aforementioned initials, or representations of body parts including hands, hearts and eyes. The positions and stances in which lovers were situated can reveal further insights into amorous exchange. For example, objects survive which represent the two lovers as looking toward one another. This communicated emotion through both an action, the gaze, and through facial expression. We might typically find the figures posed in such a way on embroideries, where a male and female figure turn to look at each other - the direction of their gaze methodically and patiently embroidered by the piece's creator. ${ }^{16}$ This expression is also found in print culture, particularly in woodcut images of courting lovers. ${ }^{17}$ The lover's gaze was a recognised trope of affection though its popularity is better documented for the eighteenth century, when single eye miniatures were produced in significant numbers. ${ }^{18}$ However even in the seventeenth

${ }^{16}$ For example: Embroidered Panel (c.1650). East Riddlesden Hall (National Trust hereafter NT): 147171. Dimensions: approx. 30 x 30 cm; Embroidered Panel Framed (c.1660). MMOA: 64.101.1302. Dimensions: 34.6 x $43.2 \mathrm{~cm}$.

${ }^{17}$ For example: A woodcut print taken from a broadside ballad, Anon., Cupids Victory of the Virgin Hearts or Love in its Colours (London: Printed for L Deacon, c.1685).

${ }^{18}$ Hanneke Grootenboer, Treasuring the Gaze: Intimate Vision in the Late-Eighteenth-Century Eye Miniatures (London: University of Chicago Press, 2013); Graham C. Boettcher, The Look of Love: Eye Miniatures from the Skier Collection (London: D. Giles Limited, 2012); 
century, the gaze communicated an individual's decision to study the profile of a lover, or at least a love interest. This was an expected and recognised amorous ritual. A gaze communicated physical attraction, admiration and also fidelity, as the lover's eyes were fixed on only one person.

Some surviving representations depict lovers gazing at one another. There are also many surviving examples, especially in portraiture, where the male gazes at the female, but the female does not stare back at the male. She would stare out of the portrait or embroidery, her eyes fixed upon whoever is studying her image. For example, at Charlecote Park, near Stratford-upon-Avon in Warwickshire, there are three paintings of Sir Thomas and Lady Alice Lucy. ${ }^{19}$ The Lucy family was one of the oldest gentry families in Warwickshire and Thomas held several influential posts in national and local governance. The first portrait of Sir Thomas Lucy (1585-1640), depicts him alone in a chair, looking to the left. In the matching portrait, Alice Spencer, Lady Lucy

Mary Fairclough, Literature, Electricity and Politics 1740-1840: 'Electrick Communication Every Where' (Hampshire: Palgrave and Macmillan, 2017), p.100.

${ }^{19}$ Cornelius Janssen van Ceulen, Portrait of Sir Thomas Lucy III (c.1620). Charlcote Park (NT): 533820. Dimensions: 127 x $101.5 \mathrm{~cm}$; Cornelius Janssen van Ceulen, Portrait of Alice Spencer, Lady Lucy (1620-5). Charlcote Park (NT): 533821. Dimensions: 127 x 101.5 cm; Cornelius Janssen van Ceulen, Portrait of Thomas and Lady Lucy with seven of their children (c.1620). Charlcote Park (NT): 533841. Dimensions: 203 x $305 \mathrm{~cm}$. There is also a second set of matching portraits of Thomas and Alice at Charlcote Park: Cornelius Janssen van Ceulen, Lady Alice Spencer (c.1620). Charlcote Park (NT): 533935. Dimensions: 72 x $58.5 \mathrm{~cm}$; Cornelius Janssen van Ceulen, Sir Thomas Lucy (C.1620). Charlcote Park (NT): 533936. Dimensions: $72 \times 58.5 \mathrm{~cm}$. 
(d.1648), also sits in a chair, facing toward her right. When these two portraits of husband and wife are put side-by-side, Thomas looks across at Alice, while Alice faces him, but gazes out of the portrait.

This formation illuminates our understanding of the ways in which men and women were expected to behave in rituals of love. In this instance, the man was more active in displaying his attraction and admiration for his female lover, than she was in returning these feelings. Rather, Alice appears as an object of beauty to be studied. While this finding does not, by any means, reveal behaviours universally, it does conform with early modern ideologies on the esteemed purity of the wife in the household..$^{20}$ The ideal woman was serene and calm, while the man was the active pursuer of this purity and goodliness. If the woman became a wife, and then a mother, then appreciation and esteem for her purity became even greater, with the lover as mother transforming into a point of veneration. ${ }^{21}$ She became the bringer and sustainer of life and lineage. The Lucy portraits certainly correspond with this notion. Katie Barclay and Rosalind Carr have suggested that loving was considered a powerful and violent act, something offered from the powerful to the powerless, and consequently women were discouraged from openly practising rituals of love. ${ }^{22}$ While their analysis focused on the eighteenth century, the dominance of the male lover's gaze in portraiture

${ }^{20}$ Sara Read, Maids, Wives and Widows: Exploring Early Modern Women's Lives 1540-1740 (Barnsley: Pen and Sword History, 2015), chapter one.

${ }^{21}$ Sara Mendleson and Patricia Crawford, Women in Early Modern England (Oxford: Oxford University Press, 2003), 33.

${ }^{22}$ Kate Barclay and Rosalind Carr, 'Women, love and power in Enlightenment Scotland' in Women's History Review, 27:2 (2017): 176-198. 
suggests that in some spaces, amorous rituals were expected to be performed by men, at least in public.

In the third portrait, Alice and Thomas's stances are identical to the two individual portraits, but the couple are painted surrounded by seven of their children. ${ }^{23}$ Thomas' admiration for his wife as mother is not only communicated by his gaze but also by the inclusion of the children in the portrait. This is further cemented by Alice's hand, which rests on her curved stomach, representing yet another pregnancy. These gazes, expressions and gestures were widely understood within the wealthy Lucy household and the wider community: they communicated the affection, admiration and attraction which Thomas felt for Alice, or at least, which he wanted to convey as feeling for Alice. Uncovering Alice's feelings is less certain. Indeed, her passivity and serenity enhanced her esteemed status within the household, and goes hand-in-hand with notions of feminine patience and restraint in the seventeenth century.

Jane W. Davidson and Alan Maddox have recently championed the importance of gestures in the early modern world: 'gestures as rhetorical devices were a vital part of everyday experience. Even for audiences beyond the educated elite, gestures were sources of information. ${ }^{24}$ Gestures formed part of a rich visual language of communication. In a world of flourishing material designs, gestures were increasingly

${ }^{23}$ Their poses may be identical due to the limited time which travelling artists had to paint their sitters, even if the sitters were wealthy enough to pay for multiple paintings. For further information see Robert Tittler, Portraits, Painters, and Publics in Provincial England 1540 - 1640 (Oxford: Oxford University Press, 2012), 60-86.

${ }^{24}$ Jane W. Davidson and Alan Maddox, 'Gestures' in Susan Broomhall, ed., Early Modern Emotions: An Introduction (Abingdon: Routledge, 2017), 172. 
represented within object design to convey the function, and often the emotional meaning, behind the object. Depictions of lovers had a twofold purpose. First, they represented the rituals of love, and they were recognisable precisely because they conveyed familiar processes. Second, they represented and cemented conventional images of amorous love, which will have influenced and dictated how lovers chose to communicate amorous expression, in both public and in private. These two functions are evident in material designs that depict lovers exchanging objects, in which the exchange of gifts became an amorous trope in itself. We find this on many types of material culture including embroideries, wooden utensils and in prints. ${ }^{25}$ Portrayals depict a male and a female figure, with one or both of the figures reaching toward each other, typically in the act of giving and/or accepting a gift. These are, in essence, objects within objects.

The types of gift represented in these exchanges were symbolic for their early modern audience, and they had specifically gendered meanings. For example, a seventeenth-century embroidered panel depicts a seated couple in wealthy dress, facing

${ }^{25}$ For example: Embroidered Panel Framed (c.1660). Metropolitan Museum of Art (hereafter MMOA): 64.101.1302. Dimensions: 34.6 x $43.2 \mathrm{~cm}$. A similar example of two shepherds, wherein the male offers the female fruit: Embroidered Panel (c.1650). East Riddlesden Hall (NT): 147171. Dimensions: approx. 30 x $30 \mathrm{~cm}$; Embroidered Panel depicting the Five Senses and Four Elements (c.1660). MMOA: 64.101.1315. Dimensions: 43.5 x 56 cm; Embroidered Casket (1678). Victoria and Albert Museum (hereafter V\&A): T.43-1954. Dimensions: 19 x 33.5 cm. Dish (1645); The British Museum: 1970, 1002.1. Diameter: 36.9 cm; Marriage Bowl (1608). Snowshill Manor (NT). Diameter: $42.5 \mathrm{~cm}$. 
one another. ${ }^{26}$ The man reaches forward, offering the woman two rich round fruits. The colour and shape of the fruit suggests that they may be strawberries. A representation of gift giving and exchange is not unusual, especially in embroidery. In another example, two separate depictions of lovers are embroidered within one canopy, and both of the men offer fruit to the women. ${ }^{27}$ In the central scene, the male lover is depicted as a shepherd with a long staff. Roze Hentschell noted that the figure of the shepherd was used to represent an older, idealised and innocent way of life, which was changing in the seventeenth century, particularly as farming methods intensified and advanced, and as commerce and trade had greater influence upon society. ${ }^{28}$ The shepherd and shepherdess were amorous tropes, often represented on romanticised quests to find a pure and idyllic type of rural love. ${ }^{29}$ In this embroidered example, the male shepherd offers a seated female figure a large bunch of purple grapes, which hang below his hand. In the other scene on the same panel, the female figure was embroidered holding

${ }^{26}$ Embroidered Panel Framed (c.1660). MMOA: 64.101.1302. Dimensions: 34.6 x $43.2 \mathrm{~cm}$. A similar example of two shepherds, wherein the male offers the female fruit: Embroidered Panel (c.1650). East Riddlesden Hall (NT): 147171. Dimensions: approx. 30 x $30 \mathrm{~cm}$.

${ }^{27}$ Embroidered Panel (c.1650). East Riddlesden Hall (NT): 147171. Dimensions: approx. 30 x $30 \mathrm{~cm}$.

${ }^{28}$ Roze Hentschell, The Culture of Cloth in Early-Modern England: Textual Constructions of a National Identity (Hampshire: Ashgate, 2008), 20.

${ }^{29}$ For example see a selection of broadside ballads: Anon., Amintas and Claudia: or, The Merry Shepherdess (London: Printed for W Thackeray, 1670); Anon., The Beautiful Shepherdess of Arcadia (London: Printed for William Gilbertson, 1660); Anon., The Faithful Shepherdess (London: Phillip Brooksby, 1675); John Fletcher, The Faithful Shepheardesse (London: Edward Allde, 1610). 
up a large flower. As with the Lucy painting, the female figure looks out of the embroidery, while he gazes toward her. He offers two fruits, possibly pears or figs. ${ }^{30}$ These fruits are suspended from a vine, held just below the male figure's waist.

Fruits and foliage were meaningful and emblematic gifts within amorous exchanges. They were readily available and could also be preserved; flowers could be pressed, fruits could be made into preserves and jams. Furthermore, in the instances outlined, it seems likely that the types of gift that the man offered his lover were understood to convey a sexual metaphor. For example, the fruit which the man offers in the embroidery resemble a pair of testicles, while in the aforementioned embroidery, the flower held by the woman was emblematic of the female gender and of a woman's virginity. ${ }^{31}$ This finding coincides with a wider catalogue of designs associated with courtship, betrothal and marriage, where friends and family projected hopes and expectations for fertility and reproduction onto a married couple of an appropriate age. In the early modern world, the growing and production of fruits were keen visual reminders of the life cycle. This iconography of flowering and blossoming fruits were then projected onto young couples. Evelyn Welch noted this connection between fruit

${ }^{30}$ Embroidered Panel (c.1650). East Riddlesden Hall (NT): 147171. Dimensions: approx. 30 x $30 \mathrm{~cm}$.

${ }^{31}$ John Fletcher, The Faithfull Shepheardesse, p.76; Henry Anderson, A Sermon preached in the Cathedral Church at Winchester (London, 1681), 20-21; Robert Albott, Englands Parnassus or the Choysest Flowers of our Moderne Poets (London, 1600). 
and sexuality in Renaissance Italy, wherein fruits were understood to infer fertility and potency. ${ }^{32}$

In these material examples, we see gifts in amorous exchange acting as a substitute or representation of the giver: when a man was depicted giving fruit to his female lover, he was offering and demonstrating his potency and fertility. The capability of the gift to act as extension of the giver was first discussed by Marcel Mauss in the 1920s and has been reflected upon and refined by many researchers. ${ }^{33}$ Natalie Zemon Davis extended Mauss's point, observing that the meaning of a gift was often an extension of the wishes of the giver. ${ }^{34}$ Illana Krausman Ben Amos described how the 'force' of gifts and giving supported 'in the creation of binding commitments and bonds of obligations. ${ }^{35}$ Most recently, Felicity Heal acknowledged that forms of

${ }^{32}$ Evelyn Welch, Shopping in the Renaissance: Consumer Cultures in Italy 1400-1600 (London: Yale University Press, 2005), 66-68. Fruits also feature in the language of early modern pornography: See Ian Frederick Moulton, Before Pornography: Erotic Writing in Early Modern England (Oxford: Oxford University Press, 2002), 88; Sara Toulanan, Imagining Sex: Pornography and Bodies in Seventeenth Century England (Oxford: Oxford University Press, 2007).

${ }^{33}$ Marcel Mauss, The Gift: Forms and Functions in Archaic Societies (London: Cohen and West Ltd., 1966), 8-10.

${ }^{34}$ Natalie Zemon Davis, The Gift in Sixteenth-Century France (Oxford: Oxford University Press, 2000), introduction.

${ }^{35}$ Illana Krausman Ben Amos, The Culture of Giving: Informal Support and Gift-Exchange in Early Modern England (Cambridge: Cambridge University Press, 2010), p.376. 
gift economy were of 'great significance' to pre-industrial societies. ${ }^{36}$ The instances of material exchange discussed here again reveals the agency of the male figure. He was the one demonstrating his prowess to the female as he was the one offering fruit to her. This visual design was understood as part of the bargaining quality of amorous rituals, in which the male offered an object to the female, as part of the process of proving himself. ${ }^{37}$ The embroideries also cement the idea that the gifts and rituals of love were strongly associated with conveying not only attraction and desire, but also fertility and potency. My interrogation of the sources reveals that, for men, material rituals of love were an opportunity to showcase their male prowess to a female, and that this was an important part of demonstrating their worth as a person to be loved.

Ideologies of fertility not only played a symbolic role for those couples in the early days of courtship or betrothal. In the late sixteenth century, Sir John Harrington gave his wife Mary (née Rogers) a ring made of gold and set with a large diamond. John gave the gift to mark a special occasion: the birth of their first son. If this ring, which John described in some detail, still survives, then sadly its connection to the Harringtons has been lost. John wrote a poem, which was later published, to explain why he commissioned the diamond ring:

\footnotetext{
${ }^{36}$ Felicity Heal, The Power of Gifts: Gift Exchange in Early Modern England (Oxford: Oxford University Press, 2014), p.5.

${ }^{37}$ For further information: Sarah Ann Robin, 'Pictures Posies and Promises: Love and the Object in the Seventeenth Century' (Unpublished Doctoral Thesis, Lancaster University, 2016), 161-163. Bronwyn Reddan, 'Gift-Giving and the Obligation to Love in Riquet à la houppe' in Merridee Bailey and Katie Barclay, eds, Emotion, Ritual and Power in Europe, 1200-1920 (Palgrave Macmillan, 2017), 23-41.
} 
Deare, I too thee this diamond commend

In which, a model of thy selfe, I send

How iust vnto thy ioints this circlet siteth,

So iust thy face and shape my fancy fitteth,

The touch will try this Ring of purest gold,

My touch tries thee as pure, though softer mold.

That metall precious is, the stone is true

As true, as then how much more precious you?

The Gem is cleare, and hath nor needs no foyle,

Thy face, nay more, thy fame is free from soile.

Youle deem this deere, because from me you have it.

I deem your faith more deer, because you gave it.

This pointed Diamond cuts glass and steel,

Your loues like force in my firm heart feel.

But this, as all things else, time wasts with wearing,

Where you, my Iewels multiply with bearing. ${ }^{38}$

${ }^{38}$ John Harington, Letters and Epigrams of Sir John Harington, together with The Prayse of Private Life (Philadelphia: University of Philadelphia Press, 1930), 150. 
John's poem is a rich description of his motivations for giving the gift, which were closely connected to the material properties of the ring and an intricate system of material metaphors. Christopher Tilley successfully argued that material metaphors have been an essential component of human communication, and consequently the expression of emotions, since ancient times. ${ }^{39}$ The ring typified Mary: it was intended as a 'model of thy self.' The purity of the gold represented the purity of Mary, her esteemed virtue heightened at the birth of their first son. The ring, however, was susceptible to wear and degradation, as was human flesh. The diamond was true and strong, and the light and sparkle of the gem represented Mary's feminine beauty. The strength of the diamond to 'cut glass and steel' conveyed the strength and power of Mary's love, and the impact this had upon John. Ultimately, Mary surpassed the power and purity of the ring. Her ability to conceive, carry and deliver a healthy child afforded her that sacred and enduring status which outstripped the material power of the ring. It has already been noted that a woman's fertility played an influential part in how men orchestrated their rituals of amorous material exchange, and how it had the potential to shape a man's admiration.

As with earlier examples, we can once again detect the agency of the male in creating and giving the gift. Some of John's motivations for creating this ring were connected to how John believed Mary complimented his needs and his desires. He noted how the delicate and skilled craftsmanship behind the ring - how well the diamond was situated within the gold ring - acted as a metaphor for how well Mary fitted into his desires and aspirations of a wife, 'So iust thy face and shape my fancy fitteth.' Here the emphasis is not so much upon Mary's character or virtues, rather an

\footnotetext{
${ }^{39}$ Christopher Tilley, Metaphor and Material Culture (Oxford: Blackwell, 1999), 4-5.
} 
attraction for her physical form and appearance. The poem enables us to determine that, much like the lover's gaze, material culture was used to communicate desire and lust for the feminine form. This was an essential tool in allowing a man to demonstrate his virility and attraction for a woman, and thus demonstrate his potency as a lover. ${ }^{40}$ The poem also reveals that rings were not just given in the early stages of a relationship but could be used to mark important events as the relationship progressed. The circular shape, symbolising eternity, may have made it a particularly fitting gift on the birth of a child.

\section{Anxieties and Objects}

Materiality played an influential role within amorous exchanges, and men and women used it to express their feelings and to try to provide proof of intent. An explosion in material goods and designs increased gift giving, which enabled more people to give goods than before. However, this growth led to an increase in objections to using materiality as means of conveying sincere expressions. ${ }^{41}$ Disputed sincerity became the subject of much amorous literature, and within these tales, objects which were meant to convey love and loyalty, became objects of mockery and deception. For example, the playwright Thomas D’Urfey penned a scene which criticised 'young Rogues' who bragged of their 'Mistresses Favours.' ${ }^{\text {'2 }}$

Here is a Garter of Sir Thomas Wittal's Lady's, here at Cue, taken from

\footnotetext{
${ }^{40}$ Jennifer Evans, Aphrodisiacs, Fertility and Medicine in Early Modern England (Suffolk: The Boydell Press, 2014), 87-130.

${ }^{41}$ Ben-Amos, The Culture of Giving, 275-306.

${ }^{42}$ Thomas D’Urfey, The Richmond Heiress (London, 1693), 8-9.
} 
above her Knee with my own Hand I'll swear; a Locket, from pretty

Peggy, Daughter to one Quicksilver a Goldsmith, at the Cawdle Cup in

Lombard-street; a Picture, from dear Ienny Flippant, a rich Widows Niece

in the old Pall-Mall; a Roman Glove, from sweet Lady Susanna Simple, in

St. Iames's-Square. And more, to shew ye that I deal with all degrees of

Females, come hither, Sirrah, there's a piece of delicate Point, from Moll

a Sempstress in the New-Exchange, to make me a Crevat; and a Head of

curious bright Hair, from my Lady Freckles Chamber-Maid, to make me a

Peruke. $^{43}$

In this speech, given by a character named Tom Romance, we see a young man boasting about a collection of objects. Tom Romance used these well-known objects to demonstrate his prowess with females. The character does this throughout, and D’Urfey described him as 'a young, vain, fluttering, lying Fellow, always bragging of his Mistresses Favours, and shewing their Presents, perpetually intriguing, and never constant to any. ${ }^{44}$ The objects would have been easily identifiable to the audience as tokens of love, sentiment and intimacy: a garter, a picture (likely a miniature), caudle cup (to keep sweet broths and posset), a glove, embroidery and hair. Tom Romance not only subverts the intimate meanings behind the rituals of which the objects were a part,

\footnotetext{
${ }^{43}$ D'Urfey, The Richmond Heiress, 8-9. A peruke is a periwig

${ }^{44}$ D'Urfey, The Richmond Heiress, 3.
} 
he also mocks the stupidity of the women for giving these gifts, naming one of them 'simple'. An early modern audience would have been aware of these rituals and how the character was abusing a system of emotional expression.

Critiques of material excess were part of wider social and religious anxieties. ${ }^{45}$ Religious, social and political commentators all noted the extravagances of the age, and while these fears were fuelled by changes beyond the growth in material culture, this increase and greater accessibility of things no doubt fuelled the nervous fire. ${ }^{46} \mathrm{Men}$ were not alone in being targeted for fickleness and emotional deception in relationships. We find similar published works decrying the false sentiment of women in amorous rituals too. Mary Evelyn, an author, penned a poem called 'The Ladies Dressing-room Unlock'd' (1690). In the poem, Evelyn described and critiqued the contents of a lady's trinket box. The box was full of objects given to her by lovers, which were all costly and excessive, but also meaningless and vacant. Here, the objects were clearly understood as a mirror of the lady, who accepted objects which were intended to provide proof of genuine and long-lasting feeling, whilst having no intention of being faithful. The poem finishes as the lady departs to meet yet another man, 'with which she

\footnotetext{
${ }^{45}$ For example: Anon., A Looking-Glass for Lascivious Young Men (London: Printed for W. Thackeray, 1620-1700); Anon., A dainty new Dialogue between Henry and Elizabeth, Being the good Wives Vindication, and the bad Husbands Reformation (c.1675).

${ }^{46}$ For example: Richard Allestree, Forty sermons whereof twenty one are now first publish'd (London, 1684), 206; Anon., The Bachelor's directory being a treatise of the excellence of marriage (London, 1696), 95; Anon., The case of the quo warranto against the city of London wherein the judgment in that case (London, 1960), 55.
} 
fancies most to play. ${ }^{47}$ While the focus of this article is not to directly comment upon women within rituals of material exchange, it is worth noting here that how women received and offered gifts was an integral dynamic of the exchange for males. Elizabeth Zeman Kolkovich recently noted that gift giving within the realms of early-modern hospitality has, in the past, been considered the 'purview' of men. However, she observes that hospitality was a 'crucial part of the expected social role of the mistress. ${ }^{48}$ As Kolkovich demonstrates, the home and objects within were intimately connected to the women who lived within that space. Many of the objects discussed in this article were part of that private, domestic realm wherein the female wielded significant power and influence. ${ }^{49}$ According to early-modern ideology, an ideal woman, particularly from a wealthy background, should be generous and devoted to her faith and her family; a woman who subverted these qualities by misusing materiality must have been able to cause significant anxieties to those who exchanged gifts with her, and to the wider network around her.

${ }^{47}$ Mary Evelyn, Mundus Muliebris: or, The Ladies Dressing-room Unlock'd, and her Toilette spread (London, 1690), 4; Anon., The Batchellors Answer to the Maids Complaint, or, The Young Men's Vindication (London, 1675), 4.

${ }^{48}$ Elizabeth Zeman Kolkovich, The Elizabethan Country House Entertainment

Print, Performance and Gender (Cambridge: Cambridge University Press, 2016), p.91.

${ }^{49}$ For example, Corinne S. Abate, Privacy, Domesticity, and Women in Early Modern England (Abingdon: Routledge, 2003). Amanda Flather, Gender and Space in Early Modern England (Suffolk: Boydell Press, 2007). 
The growth in available objects and rituals of love provoked these anxieties over insincerity and deception, especially as more people were able to access goods that previous generations could not. The well-known and valued rituals around love allowed unscrupulous men and women to abuse systems of trust, thus acquiring potentially expensive objects without fulfilling the contractual emotional obligations. Furthermore, as we have seen, amorous rituals focused upon admiration of the lover's body and appearance, including the lover's gaze. This preoccupation with the flesh went hand-inhand with fears over fickle attachment to material excess, and distractions from true and enduring emotions. Historians have identified similar concerns within debates over luxury in the eighteenth century. ${ }^{50}$ Interestingly, these critiques of material excess have tended to focus on the criticisms levied at women, rather than at males. ${ }^{51}$ The research in this article reveals that both genders faced criticisms concerning material excess and that the assumed gender expectations could be subverted caused significant anxiety.

Objects reveal an anxiety between materiality and things considered immaterial precisely because they were or are material things. The act of giving an object was an accustomed and typically essential part of early-modern love exchange, and yet it represented a great contradiction in seventeenth-century ideologies. On occasion, early-

${ }^{50}$ Sarah Jordan, The Anxieties of Idleness: Idleness in Eighteenth-Century British Literature and Culture (London: Associated University Press, 2010).

${ }^{51}$ Maxine Berg and Elizabeth Eger, Luxury in the Eighteenth Century: Debates, Desires and Delectable Goods (Basingstoke: Palgrave Macmillan, 2003), 'Part IV: The Female Vice? Women and Luxury', pp.165-206. Mary Peace, Changing Sentiments and the Magdalen Hospital: Luxury, Virtue and the Senses in Eighteenth-Century Culture (London: Routledge, 2017), chapter three, pp.85-100. 
modern men and women clearly felt conflicted in giving a material object as proof of love, yet an object could provide the ultimate proof of intent in court. ${ }^{52}$ Numerous objects were engraved with posies that expressed this conflict by emphasising the inferiority of the gift in comparison to the sentiment or person who it represented (for example, 'tho little accept it' and 'Loue eur not the Giuft but th giuer'). ${ }^{53}$ A large pewter dish commissioned for a wedding in 1674 was engraved with an inscription, 'The Gift is small the love is all. ${ }^{54}$ Here object and giver have a curious relationship, in which the object was meant to represent an emotion much more sacred and important than its material being. The inscriptions reveal that objects were used as tokens of emotional intent and feeling. What the object was intended to convey was greater and more meaningful than the object itself. A man was able to use an object for this function in courtship but there was a requirement that his subsequent actions would be the ultimate evidence of his love as genuine and he a capable and providing partner.

\section{Conclusion}

${ }^{52}$ Diana O'Hara, Courtship and Constraint: Rethinking the Making of Marriage in Tudor England (Manchester: Manchester University Press, 2000), 31-57. See also: John Gillis, For Better, For Worse: British Marriages 1600 to Present (Oxford: Oxford University Press, 1985), 16-17.

${ }^{53}$ Posy Ring (1600-1700). The British Museum: 1961,1202.29. Diameter: $1.5 \mathrm{~cm}$. Inscription: 'Tho little accept it'.

${ }^{54}$ Pewter Marriage Plate (1674). Colonial Williamsburg: 1981-210. Diameter: $99 \mathrm{~cm}$. Inscription: 'The Gift is small the love is all 1674'; Posy Ring (1600-1700). The British Museum: 1961,1202.344. Diameter: $1.8 \mathrm{~cm}$. Inscription: 'Loue eur not the Giuft but th giuer'. 
This short article does not have space enough to discuss male rituals of love in their entirety nor fully unpack what my findings could reveal for the female counterparts in each exchange. Yet through examining how a selection of men used objects to celebrate and represent their amorous feelings, a number of themes emerge. The first is the centrality and importance of gift giving itself; giving a gift was intended to convey a man's ability to provide and should therefore represent a corresponding level of wealth, as well as his potency and virility. The importance of conveying a man's fertility went in conjunction with the esteem in which women were considered as mothers and nurturers: representations of a man's fertility were a type of promise that she would attain the status of mother. However, throughout the seventeenth century, around one third of all marriages were remarriages, and as Anne Laurence observed, the English considered remarriage amongst people over child-bearing age as an important means of financial and emotional security in older age. ${ }^{55}$ Therefore, while material culture reveals the important symbolism of fertility within rituals of male gift giving, these aspirations of fertility were not applied universally. The expectation that a man was still able to gratify a woman, whether this be sexually, emotionally or financially, nonetheless remained an important ingredient in amorous material exchanges. The ability of the man to supply these things was integral to an early modern understanding of love.

Desire and attraction were important themes within rituals of gift giving. This is apparent in the lover's gaze, and in the means by which men used the materiality of an object to convey and to celebrate the beauty of their lovers. A closer examination of women and gift giving needs undertaking, but my research has revealed a more

\footnotetext{
${ }^{55}$ Anne Laurence, Women in England, 1500-1760 A Social History (London: Phoenix Press,
} 2005), 46. 
apparent type of agency in how men were able and chose to communicate their desire. While significant agency can be detected in the act of instigating a ritual of love - for example by gazing or giving a gift, the way in which this was received was also a type of agency. A lover, whether male or female, may have intended an object to convey sentiment in a particular way, but it was the recipient of the gift and how they chose to respond and use the object which ultimately determined its success. ${ }^{56}$

The sincerity and validity of these rituals was under debate in the seventeenth century. At the start of this article, I outlined how England was awash with new goods in greater number than it previously had been. This was a critical development in how people were able communicate their emotions and was likely to have grown in tandem with increasingly loud discourse on the importance of choice, or at least rational choice, when choosing a marital partner. ${ }^{57}$ More material goods also enabled new and greater scope of emotional expression after marriage, allowing husbands and wives to communicate in sentimental and longer lasting ways. These changes may have been all the more important for men because to demonstrate their prowess and virility men were expected to be more visible than women in pursuing and proving the degree of their affection. This lust then put them at greater risk of criticism for being fickle; hence material culture was a vital tool in conveying the sincerity of emotions by providing a tangible token. These factors were important to women too but given the man's need to exhibit his potency as a lover, speaking generally and ideologically, the role and responsibility of a man was more apparent and vigorous. While these rituals came under

\footnotetext{
${ }^{56}$ Nicole Eustace, Passion is the Gale: Emotion, Power, and the Coming of the American Revolution (North Carolina: University of North Carolina Press, 2008).

${ }^{57}$ O'Hara, Courtship and Constraint, 6.
} 
fire, a wider availability of goods was instrumental in a development and progression of choice, and love. There were new ways of promoting sincerity and conveying feelings of depth and respect, through long-lasting materials such as metal and stonework, but also in the creation of objects which were both time and labour heavy. Interrogating the rituals of male material exchange reveals the early modern period as one of transition in how emotions were expressed, where men had to be active, providing and apparent in love rituals but also level-headed and respectful of the esteemed chastity of the targets of their affection. 